\title{
Managing the Arroyo Seco for Flood Prevention, Erosion Control, Waterway and Habitat Restoration
}

\author{
L. A. Sanchez, C. Wang, and J. R. Laurant
}

This article was submitted to :

World Water and Environmental Resources Congress 2003

Philadelphia, PA, June 23-26, 2003

Lawrence

Livermore

February 6, 2003

National

Laboratory 


\section{Disclaimer}

This document was prepared as an account of work sponsored by an agency of the United States Government. Neither the United States Government nor the University of California nor any of their employees, makes any warranty, express or implied, or assumes any legal liability or responsibility for the accuracy, completeness, or usefulness of any information, apparatus, product, or process disclosed, or represents that its use would not infringe privately owned rights. Reference herein to any specific commercial product, process, or service by trade name, trademark, manufacturer, or otherwise, does not necessarily constitute or imply its endorsement, recommendation, or favoring by the United States Government or the University of California. The views and opinions of authors expressed herein do not necessarily state or reflect those of the United States Government or the University of California, and shall not be used for advertising or product endorsement purposes. 
UCRL-JC-151556

\title{
Managing the Arroyo Seco for Flood Prevention, Erosion Control, Waterway and Habitat Restoration
}

\author{
Lily Sanchez ${ }^{1}$, Chien Wang ${ }^{2}$, Jon Laurant ${ }^{3}$ \\ ${ }^{1}$ Lawrence Livermore National Laboratory (LLNL), Environmental Protection \\ Department; P.O. Box 808, L-627, Livermore CA 94551; PH (925) 424-4961; email: \\ sanchez39@1lnl.gov \\ ${ }^{2}$ Questa Engineering Corporation; P.O. Box 70356, Point Richmond CA 94807; PH \\ (510) 236-6114; email: cwang@questaec.com \\ ${ }^{3}$ LLNL, Facilities Maintenance? ; P.O. Box 808, L-607, Livermore CA 94551; PH \\ (925) 423-1099; email: laurant1@,1lnl.gov
}

\begin{abstract}
One of the most important tasks for a site facility manager is to ensure that appropriate channel erosion controls are applied to on-site drainage channels. These erosion controls must minimize risks to the public and structures. Water and sediment loads commonly originate from off-site sources and many of the traditional reactionary measures (installing rip-rap or some other form of bed or bank armor) simply transfer or delay the problem. State and federal agency requirements further complicate the management solution. One case in point is the Arroyo Seco, an intermittent stream that runs along the southwest corner of the Lawrence Livermore National Laboratory (LLNL) in Livermore, California. In 2001, LLNL contracted Questa Engineering Corporation to conduct hydraulic, geomorphic, and biological investigations and to prepare an alternatives and constraints analysis. From these investigations, LLNL has selected a water management plan that encompasses overall flood prevention, erosion control, and waterway and habitat restoration and enhancement elements. The most unique aspect of the Arroyo Seco management plan is its use of non-traditional and biotechnical techniques.

\section{Introduction}

The main site of Lawrence Livermore National Laboratory (LLNL) is approximately 3.3 square kilometers (one square mile) and populated by more than 8,000 LLNL employees, contractors, students, and visitors. A 1,800-foot reach of the Arroyo Seco is located along the southwest corner of LLNL and receives approximately 10 to 15 percent of the site's surface drainage. In contrast, the Arroyo Seco watershed upstream of LLNL drains close to 10 thousand acres from primarily agricultural activities. On site, locally severe bank erosion near important access roads resulted in the armoring of erosion sites with gabion baskets walls and steel sheet piling. However, these measures only deflected the high velocity flows and transferred the bank erosion problems downstream.
\end{abstract}


In 1999, the LLNL's local water resource agency required LLNL to propose a waters management plan (WMP) for the Arroyo Seco. Consequently, LLNL contracted Questa Engineering Corporation to conduct the analysis for the appropriate use of biotechnical channel stabilizations methods, rather than hard methods, to control erosion and bank instability. From this study, LLNL has selected a stable channel design for the Arroyo Seco which maximizes the beneficial uses of the channel, including habitat functions and values since the Arroyo Seco is within the federal designation of critical habitat for the California Red-legged Frog (CRLF).

This paper first provides a brief overview of the potential flooding and erosion challenges presented by the current state of the Arroyo Seco. The discussion then highlights some findings from the hydraulic, geomorphic, and biological investigations relevant to the effective management of the Arroyo Seco. Lastly, this paper describes LLNL's plans for the Arroyo Seco.

\section{Historic Revetment Installations and Current Erosion Conditions}

The 1,800-foot reach of the Arroyo Seco on LLNL is a relatively small section of the approximate 10-mile reach of the main branch of the Arroyo Seco creek upstream from LLNL. Figures 1 and 2 show the 1,300-foot project area of the Arroyo Seco on LLNL, west of where one of the site's main access roads, West Perimeter Drive, crosses the arroyo. The average channel bed slopes of the 1,300-foot length of the Arroyo Seco depicted in Figures 1 and 2 are 0.013 and 0.016, respectively. Bank heights are typically 15 to 20 feet high with bank slopes that range from $1 \mathrm{H}$ (horizontal):2V (vertical) to vertical; the top-of-bank widths in this portion of the Arroyo Seco range from 30 to 50 feet.

The 1,300-foot project reach also includes the majority of LLNL's historic revetment installations and current erosion problem areas, also depicted in Figures 1 and 2. In contrast, Figure 3 is illustrative of the remaining upstream 500-foot length of the Arroyo Seco on LLNL, east of West Perimeter Drive. This eastern reach is the most undisturbed portion of the Arroyo Seco on LLNL.

Locally severe bank erosion near the arroyo crossing at West Perimeter Drive (Figure 2) required LLNL to construct emergency repairs to protect East Avenue along the southern perimeter of the site. These repairs consisted of gabion baskets and steel sheet piling. However, flows deflected off the armoring contributed to erosion in the transition zones between the revetment and the creek bank. The picture in Figure 6 shows a typical transition zone between one of the gabion basket installations and the creek bank. Erosion control blankets were installed in some of these transitions zones but were ineffective at such steep slopes and bank erosion continued.

Development of LLNL has also increased the area of impervious surface contributing flow to the Arroyo Seco. Overbank flows from adjacent roads and parking areas are eroding the top-of-bank area of unprotected storm drain outfalls. Along approximately one third of the 1,300-foot length depicted in Figures 1 and 2, the 
channel bed has incised some 3 to 5 feet, creating over-steepened and unstable banks from toe undermining and some shallow geotechnical slump failures.

\section{Hydraulic and Geomorphic Investigations}

Under contract to LLNL, Questa Engineering Corporation used HEC-RAS to model the 2-year, 10-year, 25-year, 50-year, and 100-year recurrence flow profiles for the Arroyo Seco on LLNL. The modeling was important to identify potential flooding constraints and to design appropriate erosion controls. The modeling indicated that the lower two-thirds of the Arroyo Seco on LLNL has the capacity to pass 100-year recurrence flows with adequate freeboard to allow some channel bank planting which increases flow resistance. However, the culvert crossing at West Perimeter Drive would begin to experience backwater effects at 50-year recurrence flows. As expected in an eroding system, channel velocities are adequate to move sediment through the Arroyo Seco on LLNL.

Another important hydraulic design criteria is the erosive force exerted by flowing water impinging on the bed and banks. Using the 25-year recurrence flow profiles, calculated shear stresses were used to determine the vertical limits on the application of biotechnical bank stabilization techniques. In other words, at some point along the height of the bank, biotechnical methods can no longer withstand the shear forces exerted by flowing water. Shear stress calculations indicated that at sites along the Arroyo Seco with maximum shear stresses, a hard rock toe is necessary along the bottom 5 to 6 feet of the bank.

\section{Biological Investigations}

Although the Arroyo Seco on LLNL presents a good opportunity for some habitat enhancement, any improvements must be balanced by its real habitat value. Previous biological investigations conducted by LLNL indicate that although this reach of the Arroyo Seco could be a movement or dispersal corridor for California Red Leggedfrog (CRLF), it is unsuitable breeding habitat for this species. Biological values of the Arroyo Seco are modest as the arroyo lacks a continuous riparian canopy and most of the scattered to locally dense trees that occur along the channel banks are exotics (eucalyptus, almond, black locust). Preliminary wetland delineations determined that the entire channel bottom and lower one-fifth of the bank of the bank slopes to be waters of the U.S. However, jurisdictional wetlands were very limited because of the absence of wetland vegetation; two of the six potential wetland areas are associated with storm drain outfalls.

\section{Plans for the Arroyo Seco on LLNL}

LLNL evaluated several project scenarios and ultimately chose a system-wide approach to bank erosion management. This comprehensive erosion control plan couples traditional in stream structures with bio-technical bank and channel restoration techniques. The entire project will be conducted in two phases. The first 
phase will address immediate site-specific erosion management problem areas. The second phase will address long-term channel stability by increasing stream length and meander sinuosity.

\section{Phase One - Existing Instability Problem Areas}

The first phase of the project focuses on correcting existing instability problems. This includes traditional measures to repair gully erosion around a storm drain outfall and adding drop inlet structures to convey concentrated runoff down eroding bank slopes. These repairs will be coupled with a bank berm system to collect and redirect overland and overbank flow. Figure 4 illustrates a typical drop inlet installation. These repair measures are necessary because concentrated flows from adjacent parking lot and roads must be managed to minimize risks to the public and structures. The first phase also includes installing planted rock riprap and planted geo-grids to provide better transitions downstream existing gabion and sheet piling. Vegetated geo-grids are earth-filled structures enveloped in natural or synthetic geo-textile materials. The soil lifts are end-wrapped on the creek channel side with layers of live brush placed between the lifts. The geo-grid installations will include a rock rip-rap toe which will be keyed into the bank upstream of the geo-grid. Figures 5 and 6 illustrate typical planted rock riprap and planted geo-grid installations respectively.

\section{Phase Two - Long-term Channel Stability}

The second phase of the project addresses the long-term channel stability of the Arroyo Seco on LLNL. LLNL plans to construct left and right bank terraces to promote bedform development and increase variety of available habitat. Widening the channel and setting back the slopes will also increase channel conveyance and decrease water surface elevations. The 2:1 slope set backs will take place along approximately 300 linear feet of left bank and 550 feet of right bank; low flow terraces, at about the 1.5 year flow line, will be created on the inside of meander bends. New channel top widths will be 50 feet greater than existing top widths. The low flow terraces will be about 1 to 1.5 feet above the current bed elevations and will be approximately 10 feet wide. In addition, the newly graded bank slopes, terrace surfaces and bank top areas will provide opportunities to plant native riparian trees and shrubs.

\section{Conclusion}

Figure 7 shows the 1,300-foot project area of the Arroyo Seco that has been the subject of this paper; it illustrates the conceptual design for the left and right bank terraces and shows where the vegetated geo-grids will be installed. In whole, the project will repair existing erosion management problem areas and improve flood capacity of the channel. Furthermore, the creation of a meander planform and addition of low-flow terraces will promote the development of pool-riffle sequences, which have the potential to increase the in-stream diversity of habitat for the CRLF. 


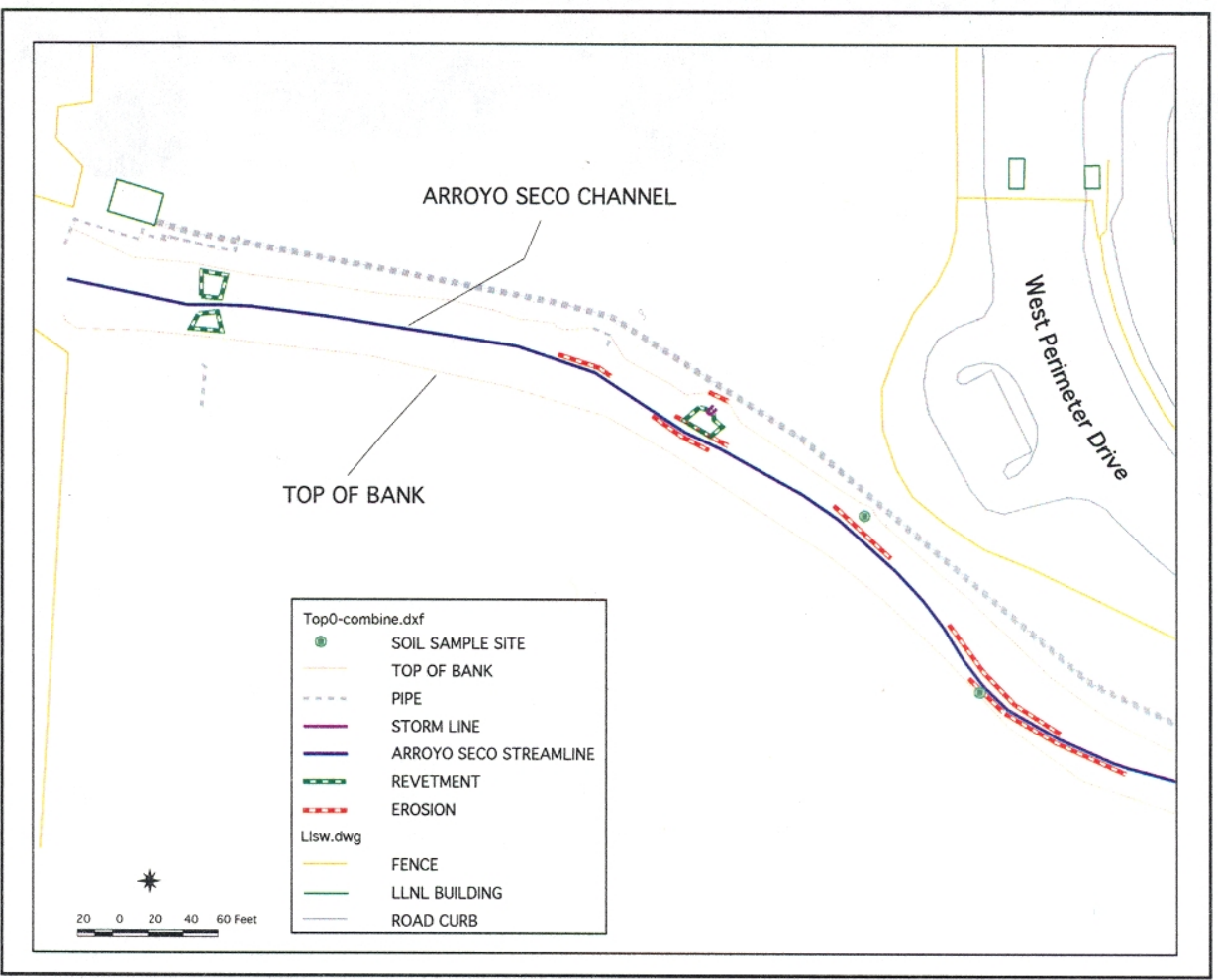

Figure 1. Arroyo Seco Project Area - West

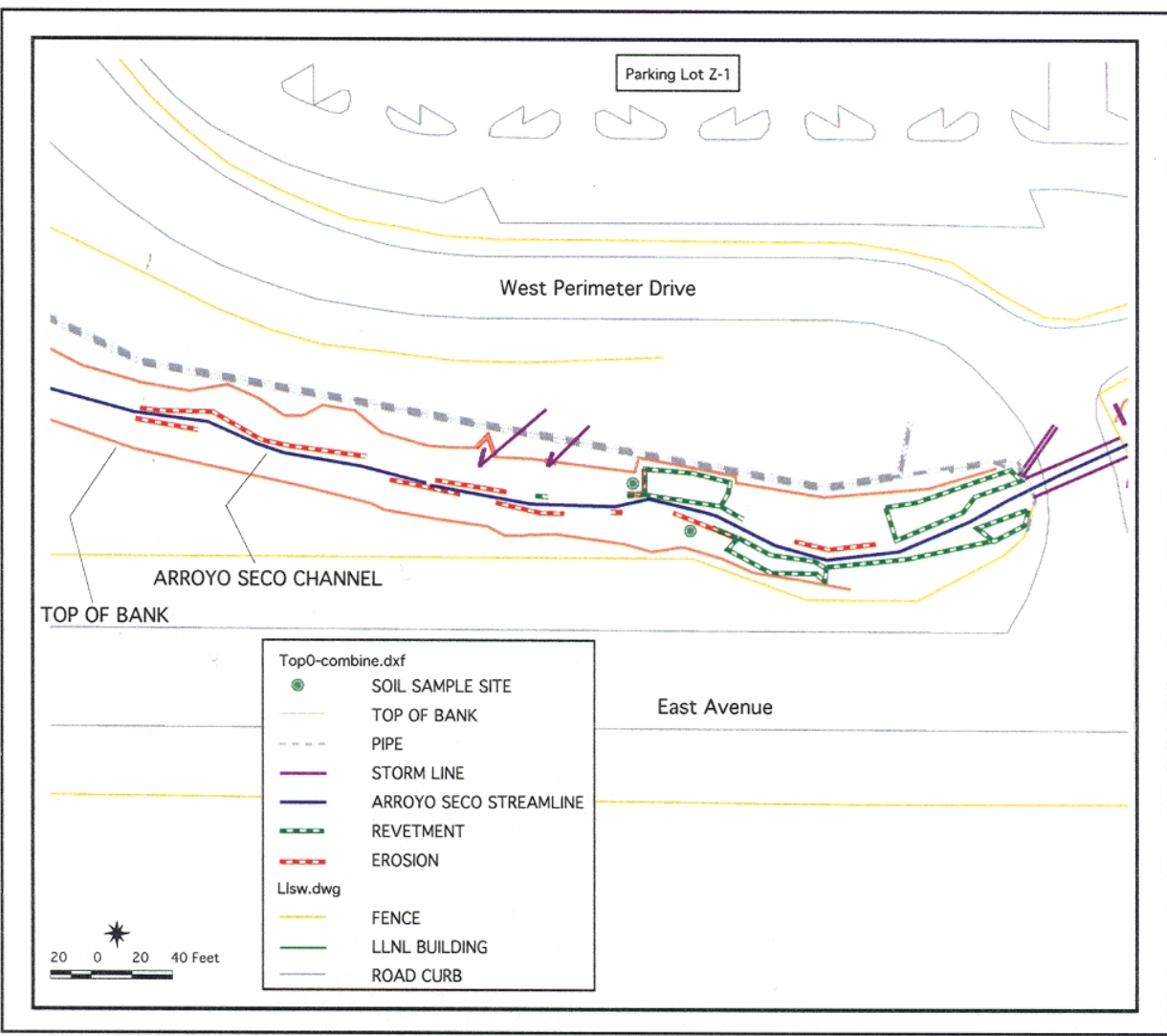

Figure 2. Arroyo Seco Project Area - East 


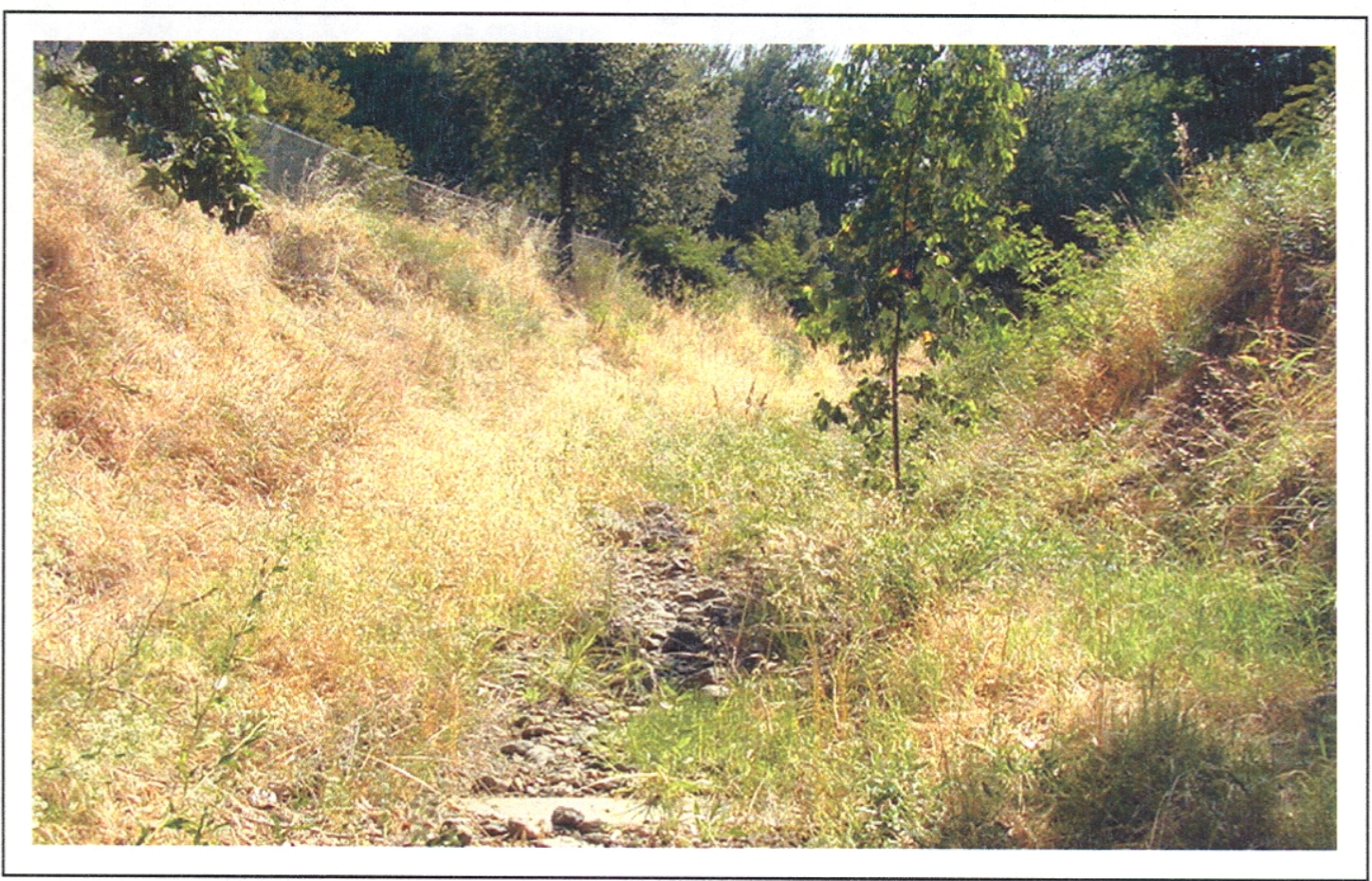

Figure 3. Arroyo Seco Upstream Project Area

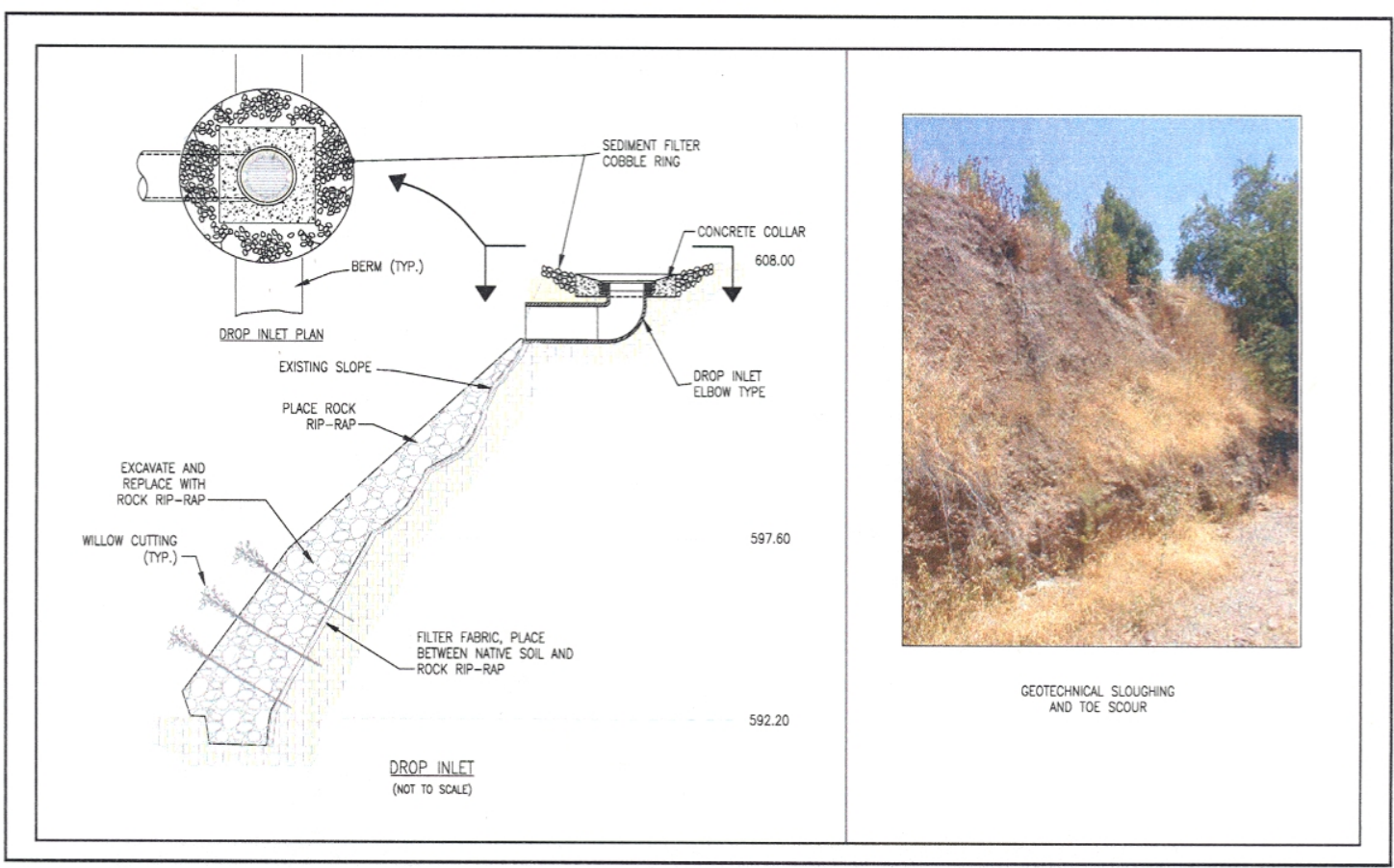

Figure 4. Typical Drop Inlet Cross Section 


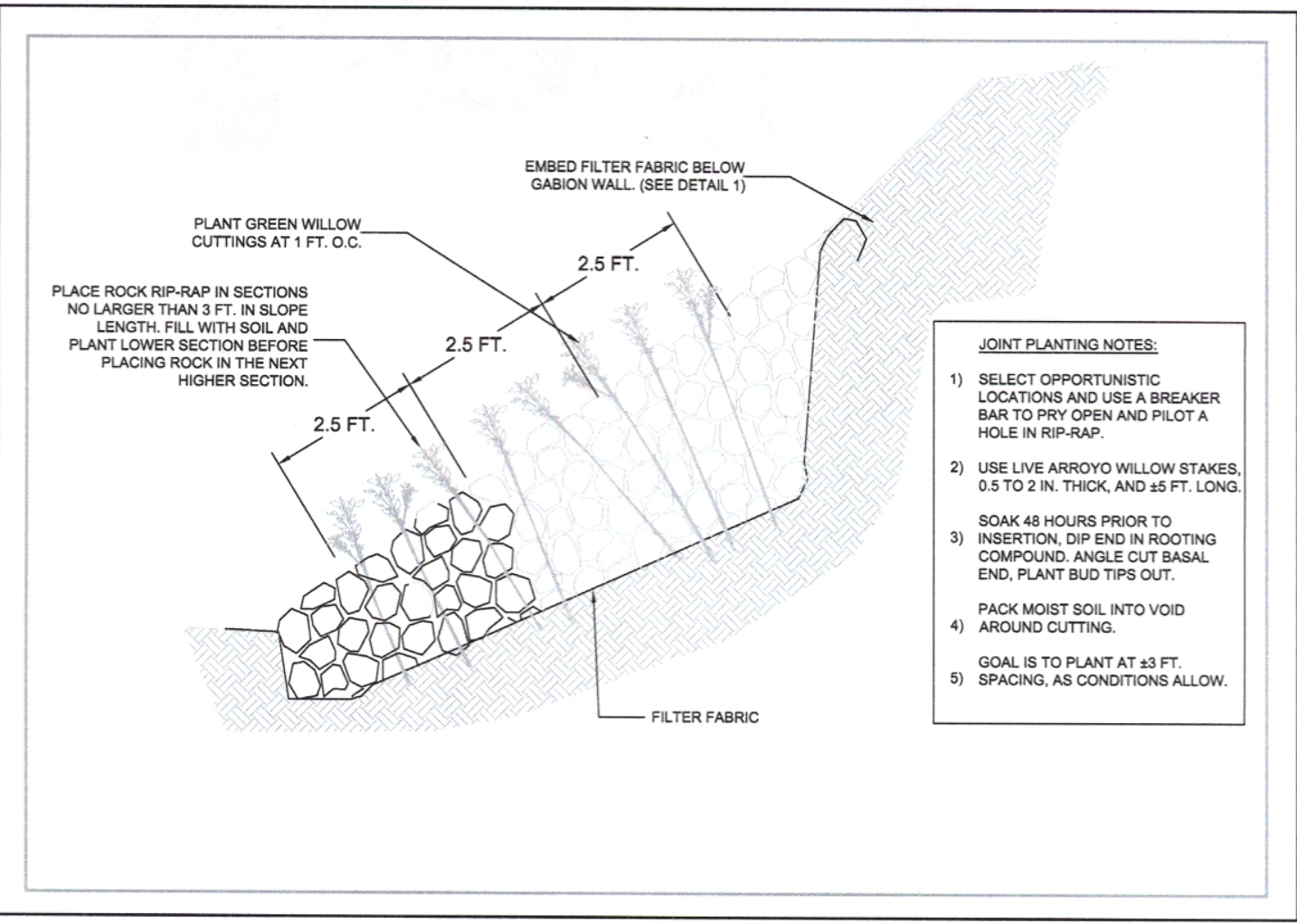

Figure 5. Typical Planted Rock Rip Rap Cross Section

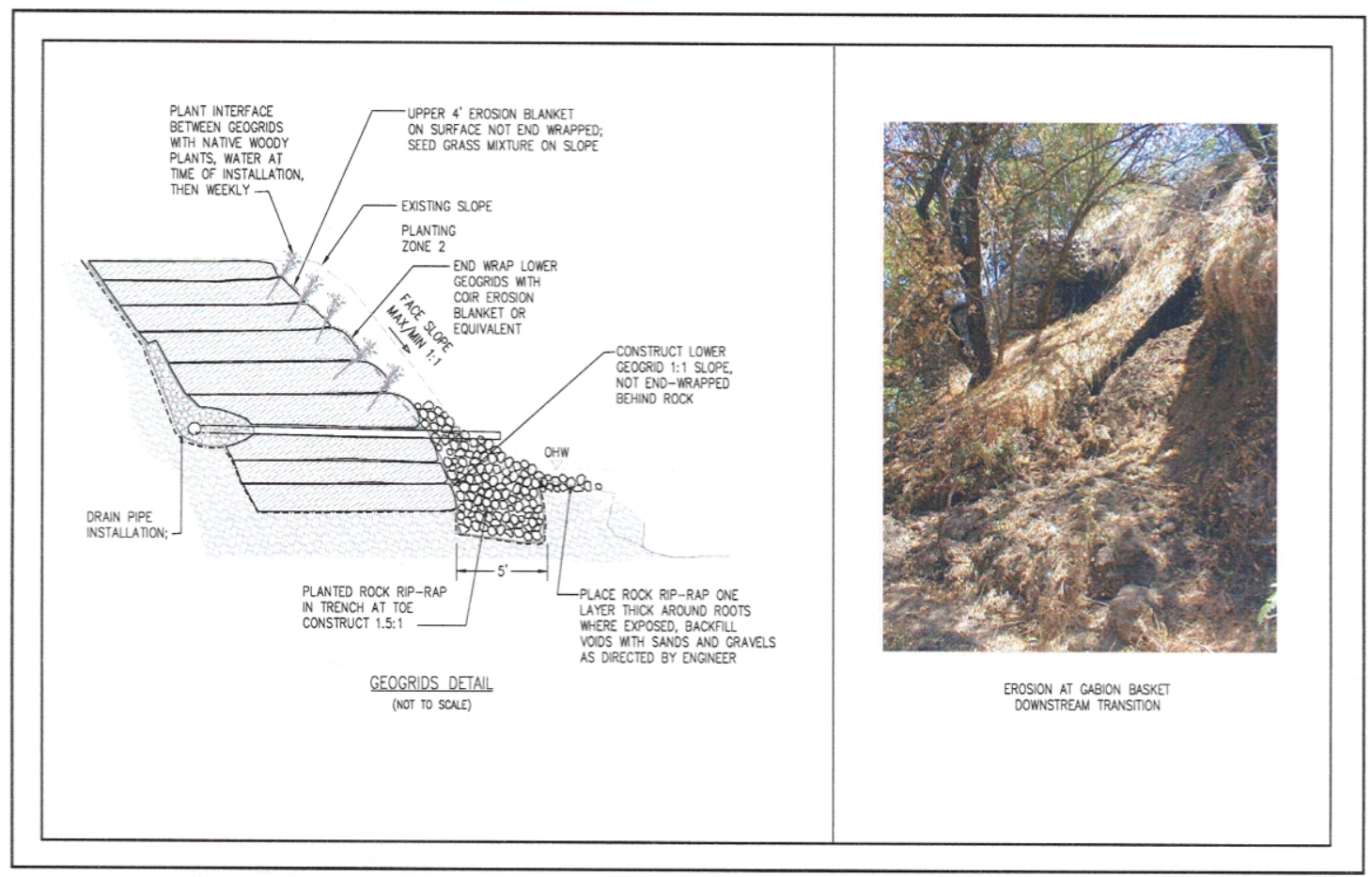

Figure 6. Typical Vegetated Geo-grid Cross Section 


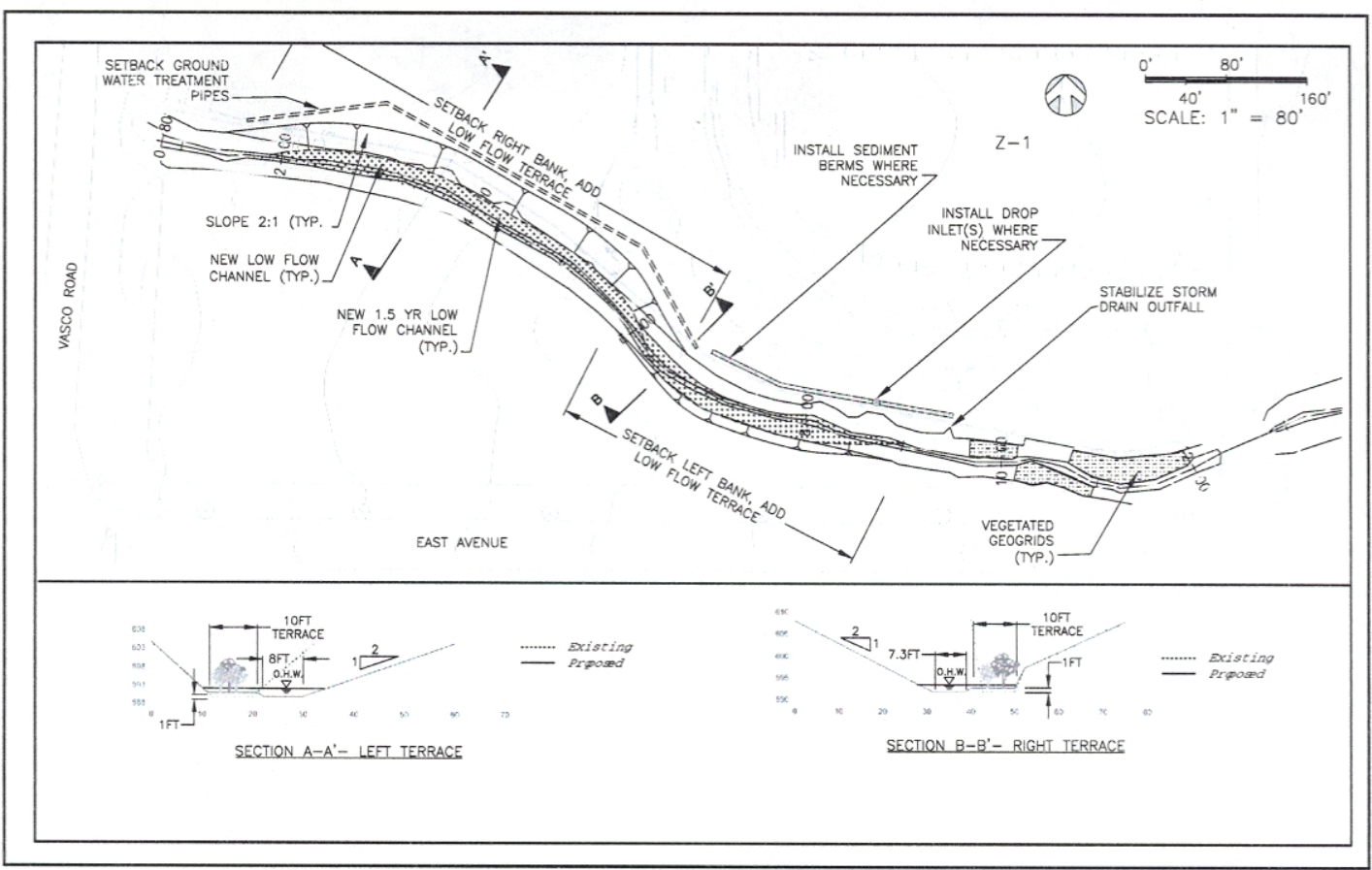

Figure 7. Arroyo Seco Project Area

\section{References}

San Francisco Bay Regional Water Quality Control Board (1999), Waste Discharge Requirements for Lawrence Livermore National Laboratory, 5-Year Maintenance Plan and Site Management Plan for Waters of the United States, Livermore, Alameda County, Order No. 99-086, October 20, 1999.

Questa Engineering Corporation (2001) prepared for LLNL, Management Plan for Waters of the United States, Arroyo Seco, P.O. Box 70356, Point Richmond, California, 94807.

This work was performed under the auspices of the U.S. Department of Energy by the University of California, Lawrence Livermore National Laboratory under contract No. W-7405-Eng-48. 